\title{
先鋭な洪水ハイドログラフの流下に伴う 水位と砂州河床高の時間変化特性 STUDY ON ALTERNATE BAR TRANSFORMATION AND WATER-LEVEL CHANGES UNDER SHARP-PEAKED FLOOD HYDROGRAPHS
}

\author{
藤堂 正樹 $^{1} \cdot$ 福岡 捷二 $^{2}$ \\ Masaki TODO, Shoji FUKUOKA
}

\author{
1 正会員 工修 広島大学大学院 工学研究科環境システム専攻（テ739-8527 東広島市鏡山 1-4-1） \\ 2 \\ フェロー会員 Ph.D 工博 広島大学大学院教授 工学研究科社会環境システム専攻（テ739-8527 東広島市鏡山 1-4-1）
}

The purpose of this research is clarifying response of degradation, aggradation, and water level when a flow characterized by sharp-peaked hydrograph runs in the place where the bed gradient is steep and alternate bars are formed. Attention is also paid to the hysteretic effect of hydrograph repetition of floods. Examinations are made by the flume experiments and numerical computations.

It is found that the variation in riverbed and water level is greatly related to flow change and alternate-bar formation. The shallow water flow in a steep river is characterized by meandering flow, which occurs during decaying and early rising stages of discharge hydrograph during which the degradation tends to go on. The water level is almost in phase with the phase of alternate bar.

It becomes clear that wavelength, wave height, and scouring depth show the characteristic change with time by the hydrograph repetition.

Key Words : Flood, alternate bars, sharp-peaked hydrograph, aggradation and degradation, water-level, hysteresis offlood hydrograph

\section{1. 研究目的}

河川上流域では，集水面積が小さく，また急勾配であ るため, 一般に流出時間は短く流量ハイドログラフが先 鋭となる. 加えて集中豪雨やダム放流も視野に入れれば, 先鋭な流量ハイドログラフの発生頻度は増加しているも のと推察される. 著者ら ${ }^{1}$ は, 断面急変部の多い急流河 川を対象とした模型実験によって，洪水時の土砂移動に ついて検討を進めてきた。

河川上流域の治水面の課題は, 急激な流量変動に対し, 河床高及び水位の変化を明らかにすることである. その 際，河道内には砂州が形成されることが一般的であり， 非定常流れにおける砂州の運動理解が基礎となる.これ に関して渡邊ら 2) は, 複列砂州から単列砂州の発生領域 を対象として, 幅広水路に非定常流と定常流を与え, 水 深変化が砂州の成長過程に及ぼす影響に着目した研究を 行っている. その結果, 非定常流を与えた場合には，波 長及び波高はその時点の水深に応じた值とはならず，過 去の水深変動の履歴を受けて変化することを示している. なお, 渡邊らの実験では定常流との比較の意味から, 比
較的継続時間の長い洪水波形を与えている.

著者らの研究の目的は，急流で掃流力が大きくかつ交 互砂州が形成される場において，急激な流量変動が生じ る場合の河床高と水位の応答解明にある.このため実際 の洪水波形を参考に, 渡邊らが対象とした洪水波形より も先鋭度の大きな波形を検討対象とした. 継続時間が短 くなるため砂州の成長が流量変動に追随できない場合も 考えられる.このため, 同一波形の繰返し履歴 3)や異な る波形を連続させた場合について，河床高や水位に与え る影響にも着目した. また, 工学的に重要な洗掘, 堆積, 水位の変動を, 砂州の形状変化との関係で検討を行った.

検討方法は直線水路を用いた実験と数值計算に拠った。 水路実験では，交互砂州の経時的な形状変化を側面から 観察し，併せて河床高の平面分布を測定した. その際, 一様勾配に整正された「初期河床高（平圴河床高）を 基準に砂州形状，洗掘深等の変動過程を観測した. さら に, 流量変動に対する流れの応答や, 砂州形状の変動原 因となる流速, 洗掘 - 堆積場の分布の経時的変化の詳細 を数值計算によって検討し, 実験結果と比較して評価し ている. 


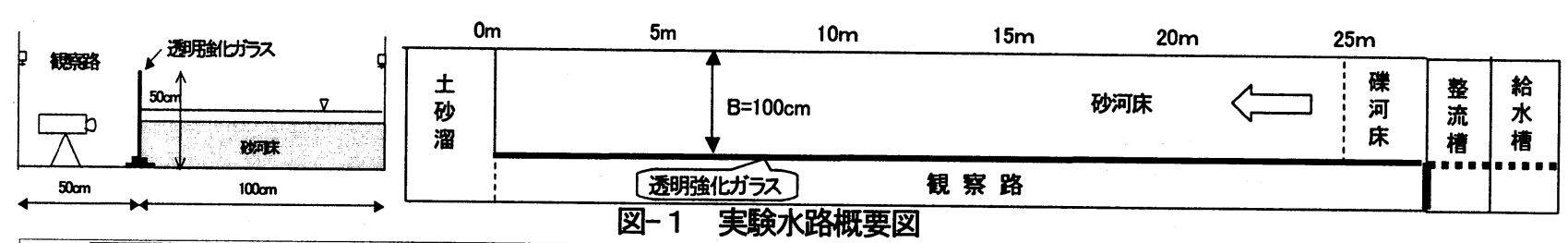

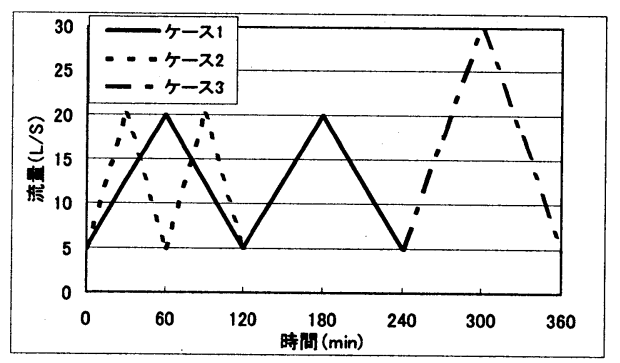

図-2＼cjkstart流量ハイドログラフ

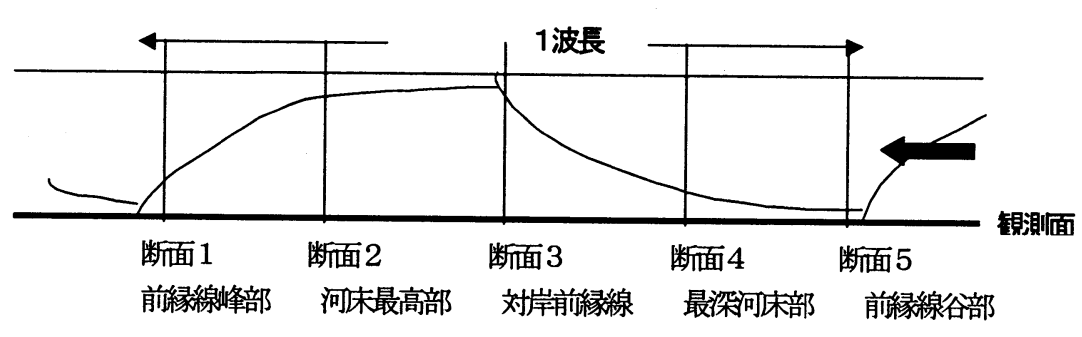

図-3 砂州形状の測定箇所

表-1 実験ケースー覧

\begin{tabular}{|c|c|c|c|c|c|c|c|}
\hline $\begin{array}{l}\text { r-x } \\
\text { No. }\end{array}$ & $\begin{array}{l}\text { 流量範囲 } \\
Q(1 / s)\end{array}$ & $\begin{array}{c}\text { 通水時間 } \\
\text { (min) }\end{array}$ & $\begin{array}{c}\text { 平均水深 } \\
\mathrm{h}(\mathrm{cm})\end{array}$ & $\begin{array}{c}\text { 工祤 一勾配 } \\
\text { Ie }\end{array}$ & $\begin{array}{c}\text { 逆算粗度 } \\
\mathrm{n}\end{array}$ & $\begin{array}{c}\text { 無次元掃流力 } \\
\tau *\end{array}$ & $\begin{array}{c}\text { 下流端流砂量 } \\
(1 / 1 \text { 仍ハ })\end{array}$ \\
\hline 1 & $5 \sim 20$ & $120 \times 2$ 茾仿ル & $1.5 \sim 4.2$ & $1 / 101 \sim 1 / 94$ & 0.021 & $0.15 \sim 0.32$ & 266 \\
\hline 2 & $5 \sim 20$ & $60 \times 2$ 侈ル & $1.5 \sim 3.8$ & $1 / 102 \sim 1 / 97$ & 0.021 & $0.14 \sim 0.32$ & 127 \\
\hline 3 & $5 \sim 30$ & $\begin{array}{c}120 \times 1 \text { 茾伤 } \\
※ \text { 絮 } 1 \text { 通水後 }\end{array}$ & $2.2 \sim 4.6$ & $1 / 104 \sim 1 / 101$ & 0.022 & $0.17 \sim 0.35$ & 379 \\
\hline
\end{tabular}

なお，水路実験では上流からの先鋭な流量ハイドログ ラフに影響を与えないような下流端条件としている. す なわち下流端での水位調節は行わず，常時，限界水深を とる条件とした.この理由は, 下流端水位を調節した場 合には, 水路下流側から生じる流路内貯留によって上流 から伝播寸る洪水流が影響を受けることが福岡ら 4の研 究によって明らかとなっているためである. 本実験では, 下流部では低下背水となるが, 下流端から $2 \mathrm{~m}$ 地点で低 下背水の影響がほぼ無くなることを確認している.

\section{2. 交互砂州形成場での非定常実験}

\section{（1）実験水路}

実験には，幅 $1.0 \mathrm{~m}$, 長さ $25 \mathrm{~m}$ の直線水路を用いた. 図-1に示すように，河床高及び水位の観察を容易とする ために水路の左岸側面は透明強化ガラスとした．初期整 正河床は勾配 1/100 の平坦河床とし， 1 サイクルの洪水 波形通水後は, 河床形態を保持した状態で 2 サイクル目 以降の波形を流下させた。河床材料には, $\mathrm{d}=0.8 \mathrm{~mm}$, 比重 2.65 の一様砂を用いた．また，左岸ガラス面には, 勾配 1/100 の「初期河床高線」を記し, 河床高及び水位 測定の基淮高とした.

\section{（2）実験条件}

上流端での流量ハイドログラフは, 水路上流端に接続 する管路に設置された電磁流速計と自動開閉バルブをコ ンピュータ制御することにより与えている. 実験に用い た流量ハイドログラフを図-2 に示す. 基本となるケース 1 では, ピーク流量を $20 \mathrm{l} / \mathrm{s}$, 継続時間を $120 \mathrm{~min} \times 2$ サ
イクルとした. ケース 2 では, 継続時間を半分とし, $60 \min \times 2$ サイクルとした. ケース 3 では, ケース 1 の 2 サイクル終了後, 継続時間を等しくしてピーク流量を 1.5 倍とした洪水波形を与えた.

継続時間の設定理由は以下の通りである. 著者らは, 前報 ${ }^{1)}$ において実在の急流河川の流れを $1 / 50$ スケール の模型実験によって検討した. その際, 洪水波形は相似 則によって最大流量 $17 \mathrm{l} / \mathrm{s}$, 継続時間 $120 \mathrm{~min}$ と定めた. 本実験についても，その水路幅等から実在中小河川の $1 / 50$ 相当のスケールと想定すれば，ケース 1 の波形は前 報で対象とした洪水波形にほぼ相当する. 従って, ケー ス 1 の波形の先鋭度は，実河川で発生し得るものであり， ケース 2 はより先鋭度の高い波形と位置づけられる.

水位と砂州河床高は, 側面測定と, 横断測定を通水中 に行った. 側面測定では図-4に示寸砂州前縁線地点, 最 大洗掘及び唯積地点に着目し, 維断位置と河床高及び水 位の経時変化を記録した. 横断測定は, 流下中の特定砂 州を対象に図-3に示寸 5 断面について, 横断方向に水位 3 点, 河床高 10 点を記録した. 測定は, 通水開始後 20 分ピッチ,ピーク流量付近では 10 分ピッチで実施した. 通水中, 上流部の河床低下を軽減するために, 流量が $151 / \mathrm{s}$ 以上の時間帯に, その時点での下流端流砂量に相 当する $60 \mathrm{~cm}^{3} / \mathrm{s} / \mathrm{m}$ の給砂を行った.

\section{(3) 実験結果}

表-1 は, 実験結果の概要である. 平均水深, エネルギ 一勾配， $\tau$ * は, 特定砂州上の水位及ひ河床高の横断測定 結果に基づく值であり, 通水時間中の変動幅を示寸. 逆 算粗度 $\mathrm{n}$ は通水時間内の平均值である. 砂州河床高と 


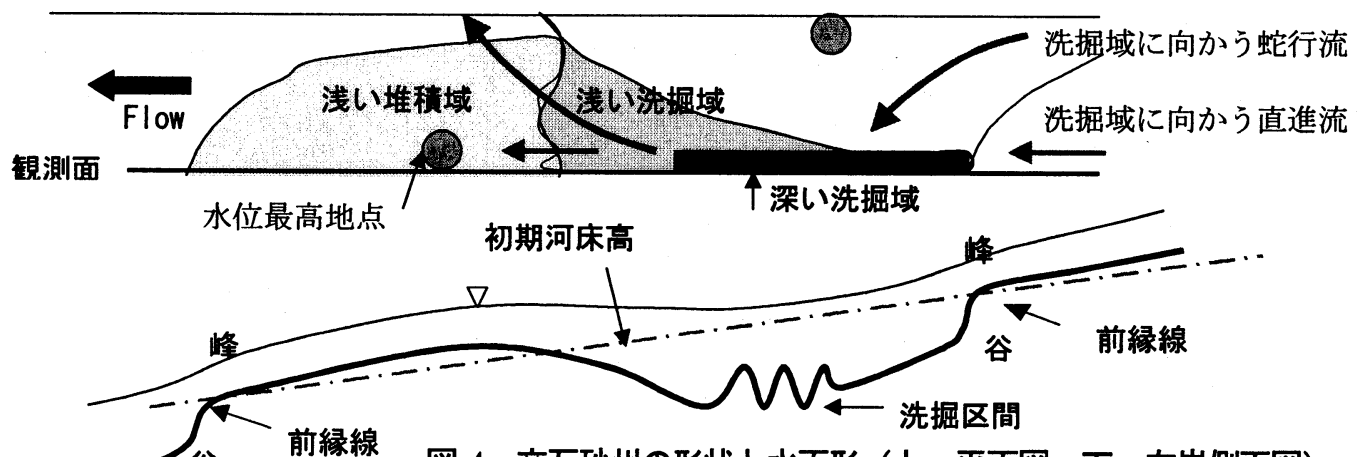

図-4 交互砂州の形状と水面形（上：平面図，下 : 左岸側面図）
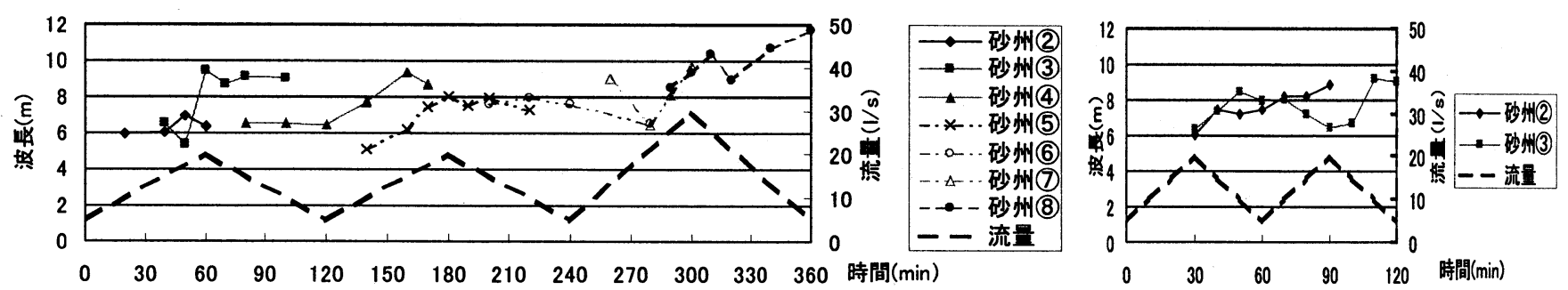

図-5 砂州波長の経時変化（左 : ケース 1 及び 3, 右 : ケース 2)
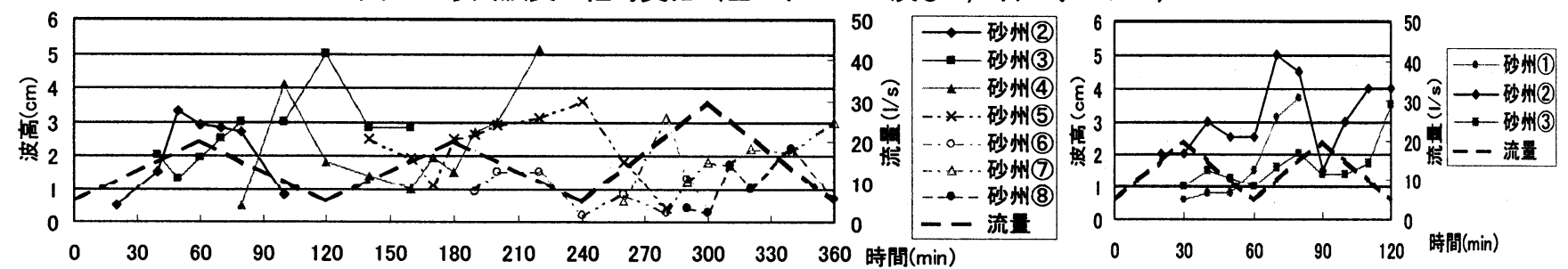

図-6 砂州波高の経時変化（左 : ケース 1 及び3, 右 : ケース 2)

水位の横断測定結果から得られた断面平均 Fr 数は, 0.7 $\sim 0.9$ 程度の値で推移した.

本実験の河床形態は, 発生領域区分 ${ }^{5)}$ より交互砂州領 域の上限に相当する.

ケース 1 では通水開始後 30 分程度, ケース 2 では 20 分程度で交互砂州前縁線の発生が確認できた. その後, 砂州の流下に伴い，新たな砂州前縁線が下流端から $20 \mathrm{~m}$ 付近に現れた. 観測時間内では, 下流端から $20 \mathrm{~m}$ 程度 の区間に，両岸で 5 波長程度の交互砂州が存在した.

交互砂州を側面から見た檤断形状を，図-4に示寸．形 状を上流加辿ると, 前縁線峰部は初期河床高とほぼ等 しく, 谷側はそれよりも低くなる. 前縁線下流側には半 波長程度の長さの洗掘区間が生じる. その下流は浅い堆 積区間が続き，下流側前縁線に至る. なお，測定時間中， 平均河床高は初期河床高に保たれている.

砂州の運動と形状に着目して考察する. 以下の図では, 左岸側面から観察できた左岸側砂州について，下流端を 通過した順に No.を記す. なお, 通水終了時に水路内に 存在した砂州は下流側から連番としている.

砂州波長の変化を図-5 に示寸. ケース $1 ， 2$ 共, 初期 段階の波長は $6 \mathrm{~m}$ 程度である. ケース 1 では, 各サイク ルのピーク流量付近で最大值 8〜9m 程度まで成長し, その值で推移した. その後波長が短くなることはなかっ た. ケース 2 では, 1 サイクルの時間内では波長が成長
しきれず 2 サイクル目以降も徐々に増加し，やはり $9 \mathrm{~m}$ 程度まで成長する. 成長過程で減水期となる場合でも波 長の短縮は認められなかった. なお, 201/s の定常流を 2 時間流下させた観察を別途実施したが，砂州波長は 9〜 $11 \mathrm{~m}$ 程度で推移した. ケース 3 の結果は, 図-5 の 3 サ イクル目である. 砂州波長は, ピーク流量 $301 / \mathrm{s}$ を過ぎ 減水期に入った段階においても増加し， $11 \mathrm{~m}$ 程度にまで 成長した. 波長が大きくなる過程では, 砂州 No.(6)のよ うに砂州の統合も確認された. 3 つの非定常実験と定常 流実験の結果から, 砂州波長は, ピーク流量に対応して 単調増加する過程にあったものと推察できる.

砂州波高は, 一般に, 砂州の横断河床高の最高点と最 低点との標高差と定義されるが，本報では，前縁線形状 の変動に着目しており, また観察の容易さから, 図-4に 示す前縁線の峰と谷の高低差を「波高」と定義する.

砂州波高の変化を図-6 に示す。波高は，ケース 1，2 の 1 サイクル目では流量増と共に大きくなるが，ピーク 流量付近で一旦増加が止まり, 減水時に再び増加する. 最大值は 2 ケース共 $5 \mathrm{~cm}$ 程度であった. また, 2 サイク ル目に入っても波高は成長するが，ピーク流量付近で一 旦小さくなりその後再び大きな值となる. ケース 3 の場 合は先の 2 ケースとは異なり, 増水段階では一旦増加す るが, ピーク流量付近では, $0.5 \sim 2 \mathrm{~cm}$ 程度の小さな值 となる．側面観察においてもピーク流量付近では前縁線 


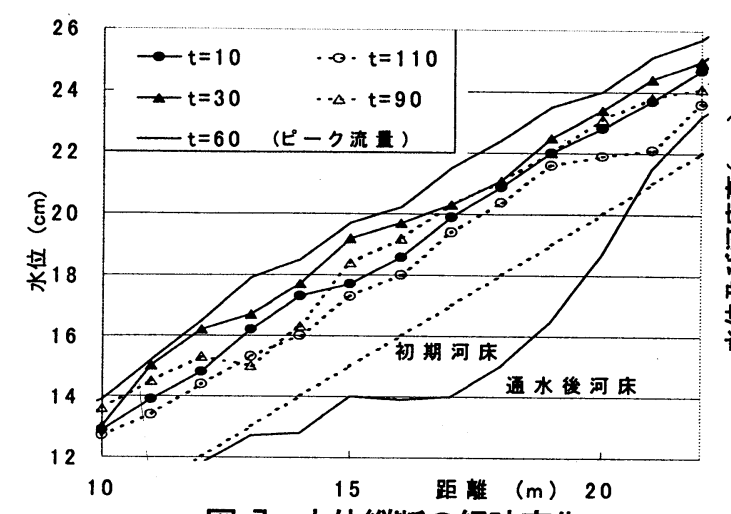

図-7 水位絴断の経時変化

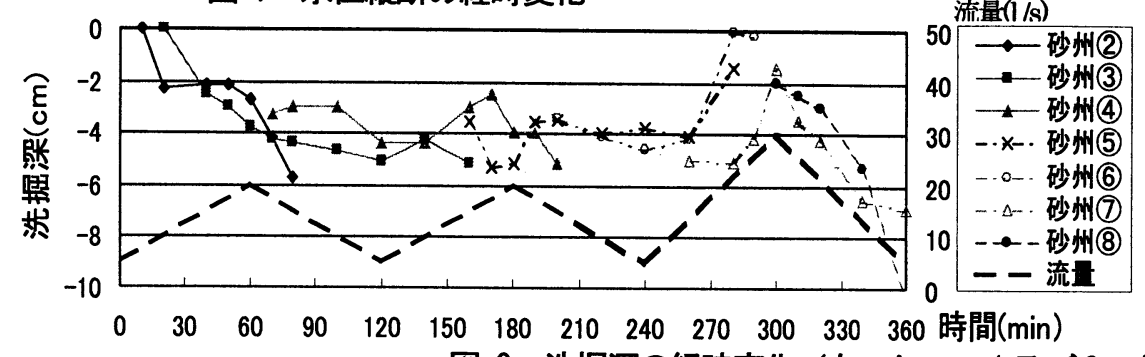

図-9 洗掘深の経時変化（左 : ケース 1 及び 3, 右 : ケース 2)

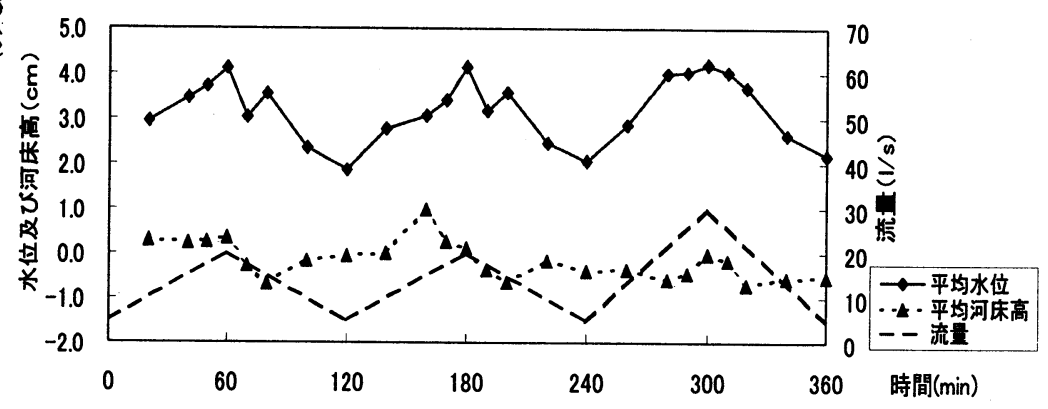

図-8 水路 $10 \mathrm{~m}$ 地点の水位及び河床高変化（ケース 1 及び 3 ）
は存在するものの，形状はやや不明瞭となる．ケース 3 のピーク流量付近では，ケース 1 の 2 サイクルの波形で 形成された砂州河床の凹凸が一旦平坦化に向かい，減水 期に入って, ケース 1 とは異なる波長と波高を持つ砂州 が再ひ形成される過程にあることが明らかとなった.

3 つのケースを詳細に見ると，峰高は，初期河床高に 対して $-0.5 \sim+1 \mathrm{~cm}$ 程度で推移し, ピーク流量付近で 低い值をとる傾向にあった. 一方, 谷高の変動はやや大 きく, 初期河床高に対し $-1 \sim-4 \mathrm{~cm}$ 程度の值で変動す る. ピーク流量付近で最も上昇しその後低下する. 波高 の変動は, 谷高の変動に拠るところが大きい.

観察より, 砂州の移動速度は流量に応じて増減するこ とが判った. 1 サイクルでの移動距離は, ケース 1 では $10.2 \sim 16.5 \mathrm{~m} / 120 \mathrm{~min}$ ，ケース 2 では 7〜 7.5m/60min ケ ース 3 では, $13.6 \sim 16.9 \mathrm{~m} / 120 \mathrm{~min}$ 程度であった.

\section{（4）水位変動及び洗掘・堆積}

図-7 は，流量変動に伴う絸断水面形の時間変化を，ヶ 一ス 1 の 1 サイクル目を対象とした側面での水位観察よ り示した結果である. 図には, 通水後の河床高も示して いる. 上流端から流入する増水期と減水期の同じ流量時 の水位縦断形を比較すると, 増水期（実線）は減水期 （破線）に比べ水面形は急勾配となっており，また， $\mathrm{H}-$ $\mathrm{Q}$ 関倸はループを描く.この結果は, 固定床で行われた 複断面蛇行水路での実験結果 4) と同じであり, 急勾配直 線水路であっても，流れの非定常性と河床形状の大きな 変化により，流路内に貯留が生じることを示している.

水面形と砂州形状との関係は, 図-4に示寸通り, 河床 の凹凸とほぼ同位相となる。“初期河床高からの水位” が最も大きくなるのは, 砂州上の浅い堆積域の中央部付 近である. 洗掘区間の水位は比較的小さい，ただし，流
量変動によって水面形状は変わる．ピーク流量付近では 一様勾配に近い水面形となるが，小流量の段階では，砂 州堆積中央部と洗掘区間とでは, 初期河床からの水位に $2 \mathrm{~cm}$ 程度の差が認められた。

下流端から $10 \mathrm{~m}$ 地点で，水位及び河床高の定点測定 を行った. 横断方向の測定点は, 水路中央と中央から左 右岸 $50 \mathrm{~cm}$ 地点の 3 点とした. ケース 1 及び 3 の測定結 果を図-8 に示す. プロットは 3 測点の平均值である. ケ ース 1 の 2 サイクルでは, 河床高は砂州の流下の影響を 受けて変動し, 水位もほぼ流量変動に応じた值となる. 平均水深は, 流量 $5 \mathrm{~J} / \mathrm{s}$ 時点で $2.2 \mathrm{~cm}$, ピーク流量 $201 / \mathrm{s}$ 時点で $3.9 \mathrm{~cm}$ であった. ケース 3 では，特徴的な水位変 動を生じた. 流量増に応じて水位上昇する傾向は同一で あるが，ピーク流量付近では水位上昇は止まる，ピーク 時水位は, ケース 1 の值とほぼ等しい. 河床は先述のよ うに平坦化するため平均水深は流量に応じて増減する結 果となった. $30 \mathrm{l} / \mathrm{s}$ 時の平均水深は, $4.2 \mathrm{~cm}$ であった.

河床高が初期河床高よりも低くなる洗掘区間は, 前縁 線の下流側にほぼ半波長程度の長さで生じる. その横断 幅は 10〜20 cm 程度である. 図-9 は，洗掘区間内の初 期河床からの低下量の経時変化である. 以下，この低下 量を洗掘媣と表記する. ピーク流量が等しく継続時間の みを変更したケース 1,2 の洗掘深は, 増水段階ではほ ぼ単調に増加する. ピーク流量付近で洗掘は一旦止み, 減水期に再び進行する. 2 サイクル目の増水段階で洗掘 媣はやや減少するが，ピーク流量を過ぎると洗掘が進み， 最大 $5 \sim 6 \mathrm{~cm}$ 程度で推移する. ケース 3 の場合, 通水開 始時点で $4 \sim 5 \mathrm{~cm}$ 程度の洗掘深は流量増と共に減少し, ピーク流量付近では $0 \sim 2 \mathrm{~cm}$ 程度となる. これは, 堆積 区域の土砂が流送され，河床全体が平坦化される結果と 考えられる. ピーク流量時を過ぎると短時間の間に急激 


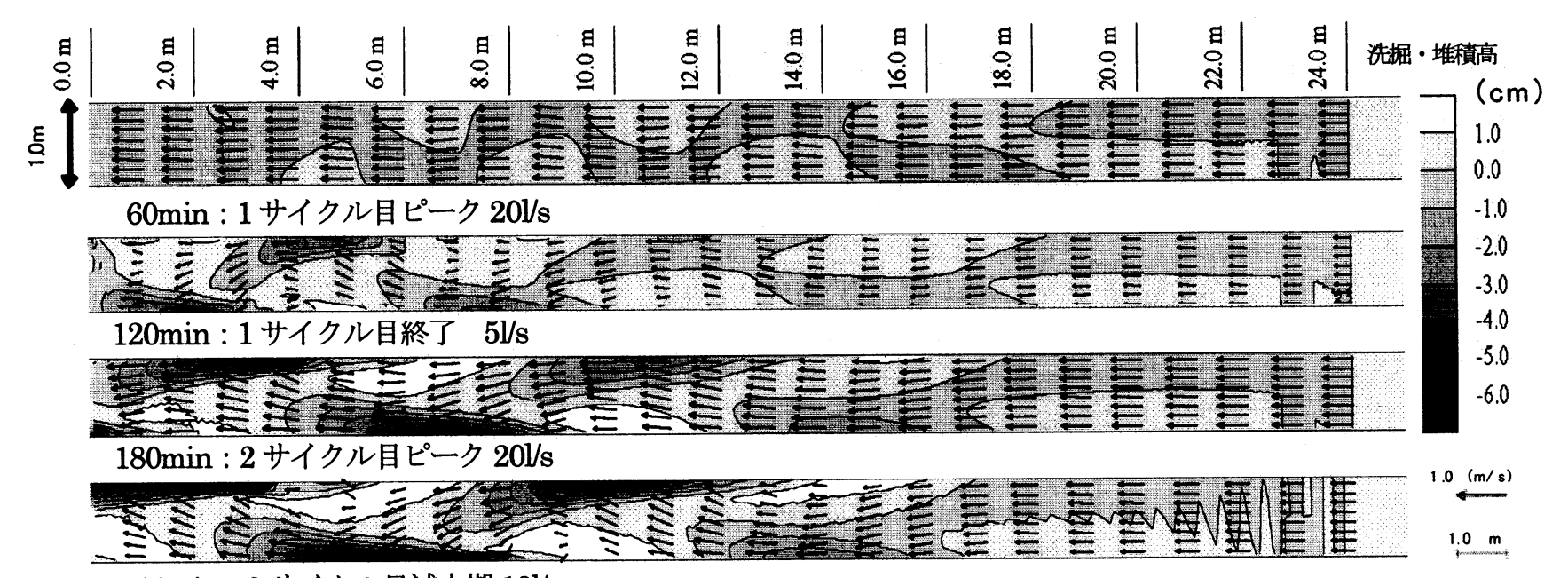

$220 \mathrm{~min}: 2$ サイクル目減水期 $10 \mathrm{l} / \mathrm{s}$

図-10 洗掘/堆積コンターと流速ベクトルの経時変化（ケース 1)

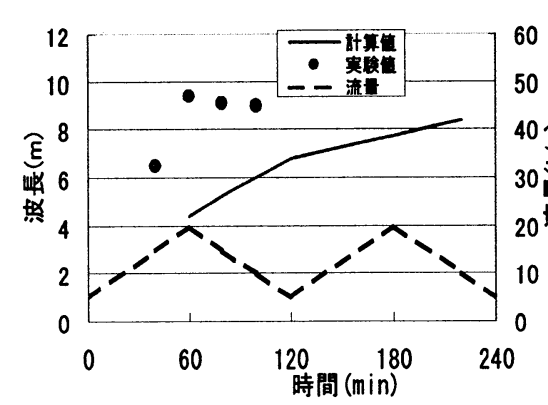

図-11 砂州波長の経時変化

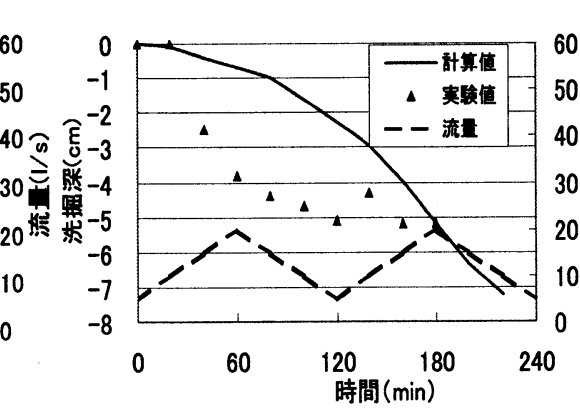

図-12 洗掘深の経時変化

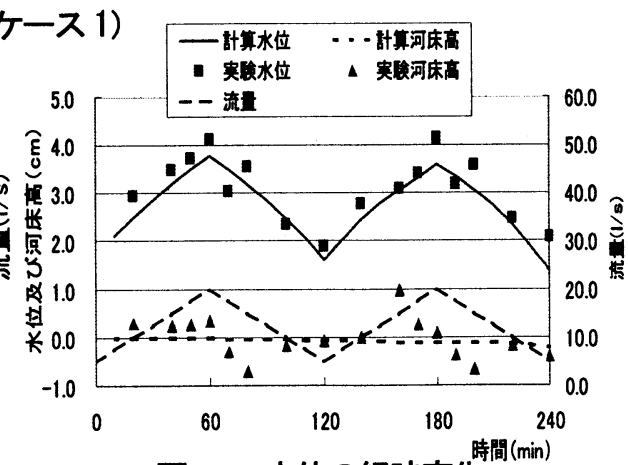

図-13 水位の経時変化
に洗掘が生じ, ケース 1,2 よりも大きい $7 \sim 10 \mathrm{~cm}$ 程 度にまで澾する。

洗掘深に影響を与えるのは，図-4に示すように，前縁 線下流部に生じる蛇行流と直進流の合流による流れの集 中である. 特に, 対岸の洗掘区間から当該洗掘区間に流 入寸る蛇行流の影響が大きい. 蛇行流の発生は, ケース 3 に明らかなように減水時に特に顕著となるため, 洗掘 はこの段階で進行し易い.

洗掘区間では, ピーク流量付近の断面平均フルード数 が 0.9 程度となる段階で波長 $20 \mathrm{~cm}$, 波高 $5 \mathrm{~cm}$ 程度の流 下反砂堆が発生した ${ }^{6}$. 数十秒程度で減哀するため, 洗 掘梁及び水位への影響は少ないものと考えられる.

堆積区間は，洗掘区間の下流側にほぼ半波長程度の長 さで生じる. 図-4 に示寸ように深い洗掘区間から下流側 に土砂輸送され，比較的広い範囲に浅い堆積が生じる. 堆積高が最大となるのは, 図-3に示す断面 2 の左岸側及 び断面 4 の右岸側である. 特定砂州の追跡観察では最大 堆積高は, $1.8 \mathrm{~cm}$ 程度であった.

\section{3. 数值計算による実験結果の再現}

\section{（1）数值計算の目的と手法}

水位と砂州河床高の時間変化の原因となる平面的な流 速及び主流線の変化特性を明らかにする目的で, 実験ケ 一ス 1 を対象に数值計算を行った.

流れの計算手法は, 前報 ${ }^{1)}$ と同様である. 鉛直方向
の運動方程式に対して静水圧分布を仮定した準 3 次元解 析手法とし，方程式の離散化は FEM 手法に拠った. 1 メッシュのサイズは, $4 \mathrm{~cm} \times 8 \mathrm{~cm}$ の直角三角形とした. 計算は, 幅 $1.0 \mathrm{~m}, 1 / 100$ 勾配の平坦河床を初期河床とし て行った. 粗度倸数は, 実験結果の逆算值 $\mathrm{n}=0.021$ を与 えた. 砂州の発生を促すための初期擾乱として, 既往研 究例 7を参考に上流端より $2 \mathrm{~m}$ 地点の右岸側に水路幅の 半分相当の幅 $48 \mathrm{~cm}$, 縦断長 $48 \mathrm{~cm}$, 高さ $5 \mathrm{~mm}$ のマウ ンドを設定した. 下流端条件は，実験と同様に限界水深 を与えている. 上流部との水深差は最大 $5 \mathrm{~mm}$ 程度であ り, 下流端から $4 \mathrm{~m}$ 程度の範用では低下背水の影響が存 在した。計算時間ピッチは $1 / 200$ 秒である.

\section{(2) 計算結果}

図-10 は, 各流量段階の河床変動量コンターに流速べ クトルを重ねたものである. 洪水波形 1 サイクル目の流 量ピーク時 60 分段階から砂州形状が明瞭に現れてくる. 砂州波長の変化を図-11 に示す. 波長は, 発生段階で は $5 \mathrm{~m}$ 程度であり, その後時間経過と共に成長を続け, 2 サイクル目の終了時点では, $8.5 \mathrm{~m}$ まで成長する. こ の值は実験值と比較すると若干小さく, 砂州の成長速度 は実験に比べてやや遅い. 初期の砂州形成が遅い点につ いては，初期擾乱の与え方も関係があるものと考える.

洗掘深の変動を図-12 に示す. 20 分経過時点で下流端 から $16 \mathrm{~m}$ 付近に生じた洗掘部は, 180 分経過時点でほ ぼ下流端に達する．その間，洗掘深は 2 サイクル目に入 
つても単調に増加し， $7 \mathrm{~cm}$ に達した。 この值は，実験の 最大值 $5.7 \mathrm{~cm}$ よりも大きい. また, 洗掘哚の増加は, 1 サイクル目の減水期から 2 サイクル目の増水期にかけて 顕著になる. 実験結果でも触れたように，洗掘原因とな る前縁線下流での流れの集中は，流量の小さい段階で特 に顕著である. 図-10 の流速ベクトルからも，流量が 5 $\sim 101 / \mathrm{s}$ 程度の段階においては, 洗掘域から対岸の洗掘 域に向から主流線が確認できる. 流速は $60 \mathrm{~cm} / \mathrm{s}$ 程度と なる. 一方, ピーク流量時点では流速ベクトルは直進性 を增して水路内を一様に流れるようになる.

$10 \mathrm{~m}$ 地点の初期河床高を基準とした水位及ひ河床高の 断面平均値について, 計算值と実験值との比較を図-13 に示す. 計算值はメッシュ横断方向の 26 点平均値, 実 験值は図-8 と同様である.

上記の結果より, 流量変動に伴う水位及び主流線の変 化は実験結果を再現できたものと考える. 一方で, 砂州 の進行速度や洗掘深については, 実験結果との差異が生 じた. これらの点に関し, 限界掃流力の設定, 流砂量の 観点から今後検討が必要と考える.

\section{4. 結論}

先鋭なハイドログラフの特徵は, 短い継続時間と流量 変動幅の大きさにある. 加えて先鋭なハイドログラフが 流下寸る場は，ほぼ例外なく急流であり，川幅水深比の 小さな流れ場で砂州河床となることが多い. 従って，水 位及び河床高の時間変化の解明には，流れの把握と共に 砂州の運動と形状変化の理解が不可欠である.

\section{（1）水位変動及び洗掘, 堆積}

急勾配の直線水路であっても, 流れの非定常性と河床 形状の大きな変化によって, 増水時と減水時の水面形は 異なり，流路内で貯留が生じる. 局所的な水面形状は, 砂州の凹凸とほぼ同位相の形状を取り, 砂州の峰部分に 相当する位置での水位は高くなる. ピーク流量時に河床 が平坦化する場合には，全断面流下の傾向となり，水深 は増加するものの水位上昇はさほど顕著とはならない。 なお, 縦断的な水位波形の経時変化と砂州形状変化との 関連については検討が十分でなく，今後の課題である.

砂州河床側岸部での洗掘原因は, 流量急変による主流 線の変化である. 小流量時には“流れの集中”により砂 州前縁線下流に洗掘が生じ, ピーク流量時には河床は平 坦化傾向となる. 河床変動の評価は, ピーク流量のみに 着目するのでは不十分である. また, 河床変動が急激で あることが短い継続時間がもたらす結果である.

これらの点は急流中小河川における特徵的な水理現象 であり，既往技術書 8) 9)等では十分に触れられていない. 水位検討や護岸等の基礎高検討の際の留意点である.

\section{（2）先鋭なハイドログラフの履歴}

先鋭なハイドログラフのもたらす履歴については, い
くつかの新しい知見を得た．水位と河床変動の「履歷」 を検討する場合, 1 洪水波形のピーク流量值，洪水継続 時間及び波形の綝返しについて考慮が必要である.

同規模の洪水波形を繰返した場合，砂州波長は時間变 化と共に増加し，ピーク流量を定常流で流下させた場合 の值に漸近していく．ただし，洪水波形の先鋭度が大き い場合, 1 洪水の継続時間内では波長の成長が流量変動 に追随できない場合が生じるが，繰返し波形を与えるこ とで一定值に漸近していくことが確認された. 砂州波高 は流量増加と共に成長するが，ピーク流量付近では一旦 小さくなり, その後再び増加する. 波形の繰返しによっ てもピーク時に波高が小さくなる傾向は現れる. なお, 波高の変動はピーク時に谷高が変動するために生じると ころが大きい, 洗掘深は, 各時点の流量ではなく, 前縁 線下流の蛇行流の影響を受けて増减する. 同規模の洪水 波形の繰返し実験では，砂州波長の場合と同様に洗掘深 は一定の值に漸近していく傾向が確認された.

本ケース 3 の第 3 波のように過去の洪水履歴よりも大 きい流量の洪水波形が流下した場合には，新たな砂州を 形成しようとする過程が確認できた. ケース 3 のピーク 流量時の水理量から判断すると, 砂州非形成に近い領域 であった ${ }^{3)}$. その場合, 河床はピーク時に平坦化傾向を 示し, 减水する短時間の間に過去の波長や波高よりも大 きな砂州形状を再度形成し，洗掘深も大きな值となった. これを実河川に当てはめれば, 既往最大規模の洪水が生 じた場合には，1洪水で急激に河床形態を変えてしまい， 特に減水時に洗掘の危険が大きいことを示唆している.

\section{謝辞 :}

研究遂行にあたり, 広島大学水工学研究室の山本輝君, 尾崎修一君の協力を得た. また数値計算では蒲生嶺行氏 に助力を頂いた. 記して謝意を表する.

\section{参考文献}

1）藤堂正樹, 福岡捷二, 浜口憲一郎 : 断面の急変する急流河川 に先鋭な流量ハイドログラフが流下した場合の水理現象, 土木学会河川技術論文集 Vo19, 2003.

2) 桑村貴志, 渡邊康玄 : 幅広水路における非定常流下での砂州 形成実験，水工学論文集第 47 巻, 2003.

3) 三輪浩, 大同淳之, 横川純 : 流量変化に伴う交互砂州の発 達・变形過程, 水工学論文集第 47 巻, 2003 .

4) 福岡捷二, 渡邊明英, 關浩太郎, 栗栖大輔, 時岡利和: 河道 における洪水流の貯留機能とその評価, 土木学会論文集 No. 740/II-64, 2003. 8

5）岸力・黒木幹男 : 中規模河床形態の領域区分に関する理論的 研究，土木学会論文報告集第 342 号, 1984.

6）福岡捷二, 興津一夫, 山坂昌成 : 急勾配移動床流れにおける 河床波の形状・伝播特性, 土木学会論文集第 323 号, 1982.

7) 横山洋, 渡邊康玄, 清水康行 : 非定常流における砂州の数值 計算, 水工学論文集第 46 巻, 2002.

8）中小河川計画検討会, 中小河川計画の手引き (案), 1999.

9）全国防災協会，美しい山河を守る災害復旧基本方針，2002.

(2003.9.30 受付) 